\title{
Review
}

\section{Apoptosis in hepatitis C virus infection}

\author{
H Bantel ${ }^{1}$ and K Schulze-Osthoff ${ }^{*, 1}$ \\ ${ }^{1}$ Institute of Molecular Medicine, University of Düsseldorf, Germany \\ * Corresponding author: K Schulze-Osthoff, Institute of Molecular Medicine, \\ University of Düsseldorf, Universitätsstrasse 1, D-40225 Düsseldorf, \\ Germany. Tel: +49-211-8112608; Fax +49-211-8115756; \\ E-mail: kso@uni-duesseldorf.de
}

Received 19.4.02; revised 3.6.02; accepted 11.6.02

Edited by M Piacentini

\begin{abstract}
Infection with hepatitis C virus (HCV) is characterized by inflammatory liver damage and a long viral persistence associated with an increased risk of developing hepatocellular carcinoma. Both in liver damage and in oncogenesis a disturbance of apoptosis has been implicated, although the underlying mechanisms in these apparently opposite processes are incompletely understood. HCV-triggered liver injury is mediated mainly by host immune mechanisms and eventually by direct cytopathic effects of HCV. Recent data shows that caspase activation, either triggered by death ligands, other cytokines, granzyme B or HCV proteins, is considerably upregulated in HCV-infected liver. Interestingly, caspase activation appears to correlate closely with the inflammatory response. Data about the role of single HCV proteins, either in cultured cells or transgenic animals models, however, are contradictory, as both pro- and anti-apoptotic effects have been observed. Nevertheless, apoptosis induction upon HCV infection may critically contribute to liver damage, while inhibition of apoptosis may result in HCV persistence and development of hepatocellular carcinoma. Cell Death and Differentiation (2003) 10, S48-S58. doi:10.1038/ sj.cdd. 4401119
\end{abstract}

Keywords: apoptosis; caspase; CD95; cytotoxic T lymphocyte; hepatitis; HCV; heptocellular carcinoma

Abbreviations: AICD, activation-induced cell death; CD95L, CD95 ligand; CTL, cytotoxic T-lymphocyte; HCV, hepatitis C virus; IFN, interferon; PBMC, peripheral blood mononuclear cell; TNF, tumor necrosis factor; TRAIL, TNF-related apoptosis-inducing ligand

\section{Introduction}

Hepatitis $\mathrm{C}$ virus (HCV) is estimated to infect up to 200 million persons worldwide corresponding to more than $3 \%$ of the world population. ${ }^{1}$ In most infected individuals ( 80\%) viremia persists and leads to chronic infection. Viral replication is rather high with an estimated rate of 10 trillion virus particles that are produced per day. HCV infects and replicates not only in hepatocytes, but also in immune cells including bone marrow and peripheral blood mononuclear cells (PBMCs). ${ }^{2-4}$ Recent studies suggested that during HCV infection $50 \%$ and more hepatocytes harbor the virus. ${ }^{5}$ Although $\mathrm{HCV}$ infection is very common, identification of patients with acute infection is rare. Furthermore, no appropriate tissue culture systems or small animal models exist to study HCV replication and viral host interactions. Consequently, little is known about the kinetics and specificity of the host response in acute and chronic infection as well as about the mechanisms that enable a small percentage of patients to clear the HCV infection, while the virus persists in the majority of infected subjects.

Chronic HCV infection is accompanied by variable degrees of hepatic inflammation, damage and fibrosis with an increased risk of developing liver cirrhosis and hepatocellular carcinoma. There is increasing evidence suggesting that liver cell damage in chronic HCV infection is mediated by induction of apoptosis. In fact, the term apoptosis was first used to describe a form of hepatocellular cell death induced in rat liver by ischemia. ${ }^{6}$ The importance of apoptosis in $\mathrm{HCV}$ infection has been proposed in view of pathomorphological features including cell shrinkage and fragmentation of the nucleus, the presence of acidophilic (Councilman) bodies and focal cell dropouts in the liver lobule. However, the contribution of either apoptosis or necrosis and the molecular mechanisms that cause liver cell damage during $\mathrm{HCV}$ infection have not yet been clearly defined. Neither do we actually understand whether apoptosis is linked to the clearance or persistence of HCV infection.

\section{CD95 receptor/ligand interaction in chronic HCV infection}

Both immune-mediated reactions and direct cytopathic effects of $\mathrm{HCV}$ might be involved in the pathogenesis of viral hepatitis. In the last few years there is growing evidence that death receptor-mediated apoptosis plays a critical role in $\mathrm{HCV}$-associated liver injury. Among the death receptors, presumably the CD95/CD95 ligand (CD95L) system plays the most important pathogenic role. A physiological relevance of CD95 in the liver was originally obtained from mice carrying mutations in the CD95 (lpr) or CD95L ( gld) gene. These animals are characterized by liver hyperplasia and a variety of autoimmune phenomena. ${ }^{7,8}$ As long as these death factors are appropriately expressed, they will be useful in maintaining tissue homeostasis, and prevent the organism from autoimmune and neoplastic diseases or may even contribute to virus clearance. However, inappropriate expression of death factors might lead to tissue destruction and organ failure. For 
instance, when an agonistic anti-CD95 antibody or recombinant CD95L were injected into mice, they died rapidly of liver failure with massive hepatocyte apoptosis. ${ }^{9,10}$ In HCV infection, upregulation of CD95 in hepatocytes as well as induction of CD95L expression in T-lymphocytes have been found to correlate with the severity of inflammation. ${ }^{11-15}$ The prevalence of CD95 in HCV antigen-positive hepatocytes was significantly higher than in uninfected cells. ${ }^{12}$ Moreover, it has been suggested that the degree of CD95 expression correlates with hepatocyte apoptosis. ${ }^{16}$ Patients with chronic HCV infection showed significantly higher CD95 levels in sera than healthy individuals. ${ }^{17}$ It has been proposed that CD95Lpositive T-lymphocytes interact with CD95-bearing hepatocytes which results in liver cell apoptosis. If this killing process works adequately, it is beneficial for the organism and may lead to elimination of virus-infected cells. However, deregulation of this system might result in liver damage. Although there is strong evidence for the upregulation of CD95 and its ligand in chronic HCV infection, no data exists about the expression of both molecules in acute infection. It is unknown whether different expression levels of CD95 correspond to the clearance of HCV, and whether CD95-mediated apoptosis is involved in acute liver damage.

Certainly, CD4 ${ }^{+}$and $\mathrm{CD}^{+}$T-cells, in particular cytotoxic T-lymphocytes (CTLs), exert a prominent role in the disease pathogenesis. CTL activity is always a two-edged sword, as it is probably involved in both clearance of virus-infected cells and liver damage. The kinetics, strength and quality of the immune response to HCV during the first weeks after infection presumably contribute very importantly to the outcome of infection. Viral clearance is usually associated with a multispecific T-cell response that persists after viral clearance, while it is not readily detectable in chronically infected subjects or in subjects who initially control the infection but in whom viremia subsequently recurs. ${ }^{18-21}$

It is commonly assumed that virus clearance requires the destruction of infected cells by virus-specific CTLs via CD95, other death receptors or the perforin/granzyme B pathway. This notion is supported by the observation that mice deficient in perforin and/or CD95 are unable to control infections by several viruses. In HCV infection, however, destruction of infected hepatocytes and viral clearance are obviously mediated by distinct T-cell populations. It has recently been observed that patients that cleared $\mathrm{HCV}$ induced an early $\mathrm{CD}^{+}$population, which failed to produce interferon (IFN)- $\gamma$ but was associated with the occurrence of acute hepatitis and only a small reduction of viremia. ${ }^{21}$ Interestingly, a subsequent switch of the $\mathrm{CD}^{+} \mathrm{T}$-cell response to IFN- $\gamma$ production coincided precisely with the rise in $\mathrm{CD}^{+}{ }^{+} \mathrm{T}$-cell response and a 5-log decrease in viremia. This suggests that hepatocyte destruction, disease pathogenesis and viral clearance are mediated by different effector mechanisms. Obviously, the first CTL response is cytolytic but inefficient in virus elimination, whereas the $\mathrm{CD}^{+}$T-cell response associated with IFN- $\gamma$ production efficiently eliminates the virus by a presumably noncytopathic mechanism.

A detailed proof for the dissection of hepatocyte destruction and viral clearance must await further studies, for instance in chimpanzees, in which the extent of infection and nature of the immune response can be evaluated in the liver. It should be noted that in the above mentioned report, immune-mediated destruction of hepatocytes was reflected by elevated serum markers of liver disease. Several studies, however, point out that apoptosis and caspase activation are dissociated from serum transaminase levels (see below). IFN- $\gamma$ production is certainly an important mechanism for virus clearance, but also acts as a regulator of apoptosis triggered by death receptors and other mediators. Neither CD95 expression nor the degree of liver injury correlate with intrahepatic viral load, ${ }^{22-24}$ supporting the hypothesis of indirect immune-mediated mechanisms in hepatocyte apoptosis. In such a scenario, $\mathrm{Th}_{1}$ cytokines, such as tumor necrosis factor (TNF) or IFN- $\gamma$ might upregulate CD95 in hepatocytes as well as CD95L in T-lymphocytes. ${ }^{25,26}$ Interestingly, CD95L may also exert proinflammatory activities by inducing the secretion of interleukin- $1 \beta$ and other cytokines that are responsible for leukocyte infiltration. ${ }^{27}$ Thus, the HCV-mediated immune response might be closely associated with CD95-triggered hepatocyte apoptosis.

\section{The role of TNF and TRAIL receptors in chronic HCV infection}

In addition to CD95, the TNF system has been implicated in the pathogenesis of $\mathrm{HCV}$-mediated liver disease. HCV induces the expression of TNF in human liver, and HCVspecific CTLs have been shown to secrete TNF- $\alpha$ in vitro. ${ }^{28-}$ ${ }^{30}$ Moreover, plasma TNF level is increased in patients with chronic HCV infection. However, elevated plasma TNF as well as soluble TNF receptor-I levels were mainly observed in acute hepatitis and correlated with serum levels of transaminases. ${ }^{31}$ In mouse models of galactosamine/TNF or endotoxin-induced hepatitis, in which TNF plays an essential role, apoptotic liver injury is followed by severe necrosis and release of transaminases. ${ }^{32,33}$ Moreover, in the T-cellmediated model of concanavalin A-induced hepatitis, in which TNF also plays a major role, caspases might not be involved in liver cell damage. ${ }^{34,35}$ Overall, TNF might play a role more in hepatic necrosis and inflammation than in apoptosis.

In contrast to CD95 and TNF, little data exists about the role of TRAIL in liver diseases. However, several laboratories are currently studying the involvement of TRAIL and its receptors in viral hepatitis. It was suggested that the TRAIL system might have evolved as a prime physiological mechanism in order to eliminate virus-infected cells. ${ }^{36}$ In an infection model with restricted cytomegalovirus gene expression or productive adenovirus infection in epithelial cells that are normally resistant to TRAIL-induced apoptosis, TRAIL sensitivity is induced upon virus infection and accompanied by an upregulation of TRAIL receptors. ${ }^{37}$ Thus, TRAIL has antiviral activity by inducing apoptosis of virus-infected cells while leaving non-infected cells intact. This idea is supported by the fact that TRAIL mRNA and protein production in primary macrophages is switched on by infection with human immunodeficiency virus-1. ${ }^{38}$ Moreover, IFN- $\gamma$ but also IFN- $\alpha$ and $\beta$ induce TRAIL and TRAILreceptor expression, thereby sensitizing cells to apoptosis. $^{36,39}$ IFN-induced upregulation of TRAIL in immune cells 
including monocytes, dendritic cells and NK-cells might contribute to the antiviral cytotoxicity of these cells. ${ }^{39-42}$ Recently, IFN- $\gamma$ has been demonstrated to induce TRAILmediated apoptosis also in human hepatoma cells. ${ }^{43}$ Since IFN- $\alpha$ plays a major role in the treatment of HCV infection, it would be of great interest to investigate whether IFN- $\alpha$ therapy, either alone or in combination with ribavirin, induces apoptosis of infected hepatocytes via TRAIL signaling.

Whether TRAIL will find an application as a potential antiviral agent has to be shown in future studies. One of the most appealing features of TRAIL is that it does not seem to have the extreme liver toxicity that has precluded the use of CD95L and TNF, which cause massive hemorrhagic liver necrosis. Since TRAIL exerts its cytotoxicity in vivo only in transformed or infected cells without causing apoptosis in normal healthy tissue, ${ }^{44}$ it was believed to be safe for use in human cancer and infectious diseases. However, unexpected warning concerns recently arose when human hepatocytes were shown to be TRAIL-sensitive. ${ }^{45}$ In this study it was demonstrated that TRAIL is able to cause massive apoptosis of normal human hepatocytes but not of those isolated from mice or monkeys. Re-evaluation of these results, however, now suggests that the toxicity for human hepatocytes may depend on the preparation and version of the recombinant TRAIL used. ${ }^{46}$ Moreover, a new agonistic TRAIL-R2 antibody has been recently described which triggered apoptosis in primary hepatocellular carcinoma cells but not in normal hepatocytes. ${ }^{47}$ Certainly, further studies and clinical trials are needed to evaluate the potential side effects, hepatotoxicity and therapeutic potential of TRAIL in human diseases.

\section{Activation of caspases is associated with HCV-mediated inflammatory liver injury}

Despite the rapid elucidation of apoptotic pathways, it is almost unknown whether and to what extent caspases as the main executioners of apoptosis are activated in liver diseases. Effector caspases, such as caspase- 3 and -7 , were shown to be activated in models of mouse hepatitis induced by TNF or CD95L. ${ }^{48,49}$ The importance of caspases in hepatitis is underscored by studies with pharmacologic caspase inhibitors, which potently suppressed experimental hepatitis. ${ }^{50,51}$

Recently, our laboratory was able to demonstrate that various liver diseases are characterized by elevated caspase activation and apoptosis. ${ }^{52,53}$ Using novel antibodies specific for the active forms of caspase- 3 and -7 as well as for the cleaved caspase substrate PARP, we found that caspase activation was elevated in a considerable percentage of hepatocytes in liver biopsies from chronic HCV infection. ${ }^{54}$ Most striking was the fact that, depending on the grade of necroinflammatory injury, caspase activation was detectable in $7 \%$ to $20 \%$ of the hepatocytes, whereas control individuals displayed almost no caspase activity (Figure 1). In several previous studies, the amount of liver cell apoptosis has been assessed by standard techniques based on detection of DNA fragmentation such as the TUNEL method. In these studies, apoptosis was also elevated compared to healthy liver, but was rather low and never exceeded $0.5 \%$ of apoptotic hepatocytes in viral hepatitis. ${ }^{24,55}$

One reason for the discrepancy between the low number of TUNEL-positive cells and the high number of cells revealing caspase activation might be explained by the time course of biochemical events in apoptosis. DNA fragmentation is recognized as a late event in apoptosis, whereas caspase activation occurs earlier than DNA cleavage. It has also been found that some forms of apoptotic cell death, even in hepatocytes, are not always associated with DNA fragmentation. ${ }^{56,57}$ Finally, it is conceivable that in late stages of apoptosis when DNA fragmentation occurs, apoptotic cells are rapidly phagocytosed and therefore escape detection by TUNEL staining. Thus, the approach of quantifying apoptosis by morphologic criteria and DNA fragmentation may underestimate the number of cells actually undergoing apoptosis.
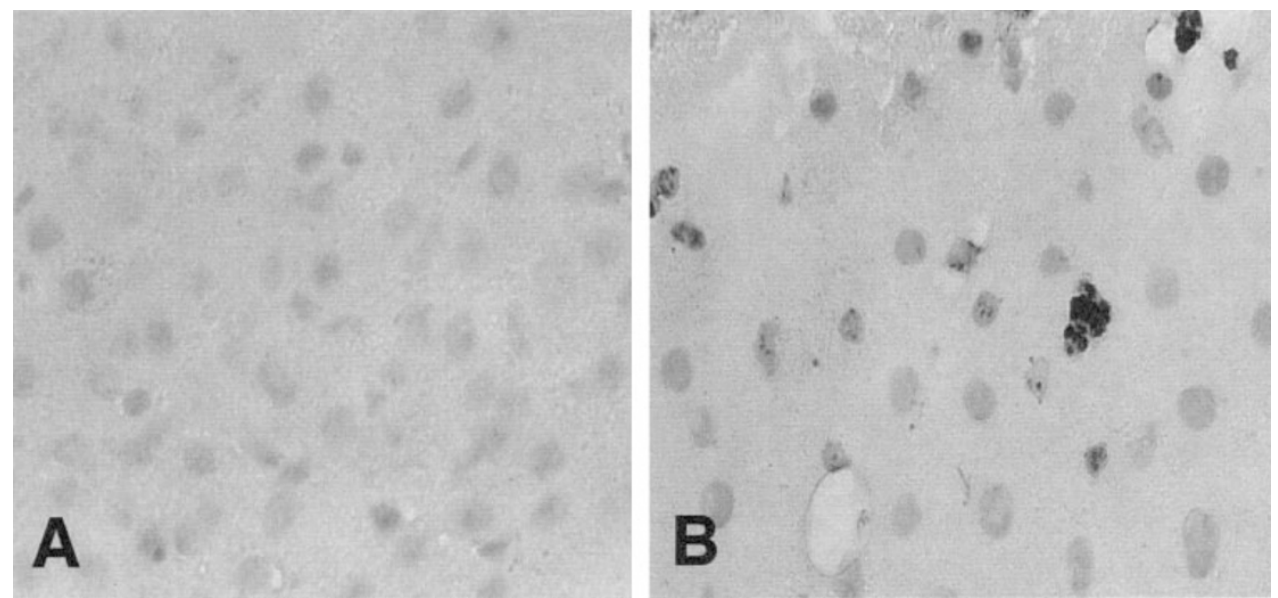

Figure 1 Immunohistochemical detection of caspase-3 activation in liver biopsies. Liver tissues from a control person and a HCV patient were analyzed with activation-specific antibodies for caspase-3. Almost no immunostaining was detected in normal liver (A), whereas a liver biopsy from the patient with chronic HCV infection showed intense staining with the antibodies (B). Note that the antibodies labeled hepatocytes with apoptotic morphology as well as cells with a rather intact cell nucleus 
Another interesting finding from our studies was that the extent of caspase activation correlated significantly with the grade of necroinflammatory disease activity. This link might be related to the finding that apoptotic cell death can trigger neutrophil recruitment into the liver and transmigration into the parenchyma. ${ }^{33,58}$ For instance, apoptosis as well as neutrophil transmigration and hepatic injury could be completely prevented by treatment with a caspase inhibitor. $^{33}$ Interestingly, mice treated with anti-CD95 showed increased caspase-3 activity, which was accompanied by activation of the pro-inflammatory transcription factor AP1 and enhanced chemokine production. ${ }^{59}$ These events were followed by hepatic neutrophil recruitment. When apoptosis was prevented by pretreatment of mice with a caspase- 3 inhibitor, AP1 activity, chemokine production and hepatic inflammation strongly declined. These data along with our results indicate that caspase activation and apoptosis are associated with the severity of inflammation in both experimental hepatitis and chronic HCV infection.

Similar to a previous study, ${ }^{24}$ we did not find a correlation between caspase activation and serum HCV levels. Moreover, the degree of HCV-mediated liver damage did not correlate with the number of infected hepatocytes. Thus, it is not clear whether caspase activation is directly related to HCV-mediated liver damage. Kinetic analysis of viral turnover in patients indicated that HCV infection is a highly dynamic process with a short half-life of viral particles and HCV-infected cells. ${ }^{60}$ It has been calculated that the daily turnover of HCV-infected cells may be as high as $13-25 \%$. Assuming that in patients with chronic HCV infection approximately $50 \%$ of the hepatocytes are infected, this would mean that between 6.5 and $12.5 \%$ of infected hepatocytes are killed daily. ${ }^{55,61}$ It is remarkable that this number is very similar to the amount of cells with active caspases. However, as discussed above, it has to be considered that immune mechanisms might also indirectly contribute to cell death of non-infected hepatocytes.

Finally, apoptotic hepatocytes might undergo secondary necrosis. In vivo studies showed that apoptosis of hepatocytes might be accompanied by elevated transaminase levels, but that the release of transaminases was considerably lower in apoptosis than in necrosis. According to previous studies, ${ }^{24,55}$ we did not find a significant correlation of caspase activation and serum transaminase levels. Thus, relative differences in the occurrence of apoptosis and necrosis could explain why transaminase levels and caspase activation are not linked to each other. These results further suggest that chronic liver damage and hepatocyte loss by apoptosis can occur in HCV-infected patients without overt biochemical changes. This may explain the progressive nature of $\mathrm{HCV}$ infection that can be seen in asymptomatic patients with normal transaminase levels. ${ }^{62}$

At present, many open questions remain regarding the role of apoptosis and caspase activation in HCV infection. It is actually unknown how many hepatocytes are indeed killed during chronic HCV infection, and to which extent apoptotic, necrotic or intermediate events contribute to this process. Furthermore, no data exists whether caspase activation is involved in the resolution or persistence of virus infection. Nevertheless, the positive correlation between caspase activation and inflammatory liver damage in HCV infection might open challenging possibilities for the development of therapeutic agents. Monitoring of caspase activation might provide a diagnostic tool to detect the degree of HCV-mediated inflammatory liver damage and to evaluate the efficacy of HCV therapy.

\section{Potential mechanisms of caspase activation in chronic HCV infection}

The upstream molecular mechanisms by which caspases are activated in chronic HCV infection are rather unknown. There is evidence for the involvement of death receptors but also of other mediators including the perforin/granzyme B and IFN system (Figure 2). In death receptor-mediated apoptosis, CD95L-, TNF- and TRAIL-induced signal transduction leads to the formation of a death-inducing signaling complex which results in the proteolytic processing of caspase- 8 and activation of downstream effector caspases. ${ }^{63}$ Accordingly, activation of caspase-3 and -7 was detected in hepatocytes from mice treated with agonistic anti-CD95 antibody as well as in cultured hepatocytes incubated with anti-CD95. ${ }^{51,59,64,65} \mathrm{~A}$ broad-range caspase inhibitor completely abolished caspase activation and hepatocyte apoptosis in vitro and in vivo. ${ }^{48,50,64}$ Besides death receptors, the granzyme B/perforin pathway certainly plays a role in HCV-mediated apoptosis. Perforin is released from granules of cytotoxic T-lymphocytes and NKcells to form pores within the target cells. This allows the entry of concomitantly secreted granzymes that can directly cleave caspase- 8 and thereby activate effector caspases in target cells. $^{66,67}$

Hepatocytes represent most likely so-called type-II cells, in which the direct activation of caspase-8 is not sufficient to induce cell death, but in addition requires the amplification by a mitochondrial pathway. In this scenario, caspase8 activation causes the proapoptotic cleavage of Bid, which induces the mitochondrial release of cytochrome $c$ and formation of an apoptosome complex. For instance, hepatocytes transgenically overexpressing $\mathrm{Bcl}-2$ were resistant to anti-CD95-induced liver damage and the survival rate of these mice was greatly enhanced. ${ }^{64,68}$ Moreover, it was demonstrated in a mouse hepatitis model that treatment with anti-CD95 antibody not only causes caspase activation, but also a decrease of mitochondrial membrane potential and cytochrome $c$ release. ${ }^{69}$ Recently, it was demonstrated that Bid knockout mice treated with anti-CD95 display reduced lethality, underscoring the importance of the mitochondrial pathway for hepatocyte apoptosis. $^{70}$ Thus, this data indicates that also in HCVmediated liver injury apoptosis triggered by death receptors or other mediators might require a mitochondrial amplification pathway.

Considering the important role of IFNs in antiviral defense, it is not unexpected to find that IFNs modulate apoptotic pathways by several mechanisms. The geneinducing effects of IFNs are largely controlled through the JAK-STAT pathway. It has been demonstrated that the potentiation of death receptor-mediated apoptosis by IFN- $\gamma$ 


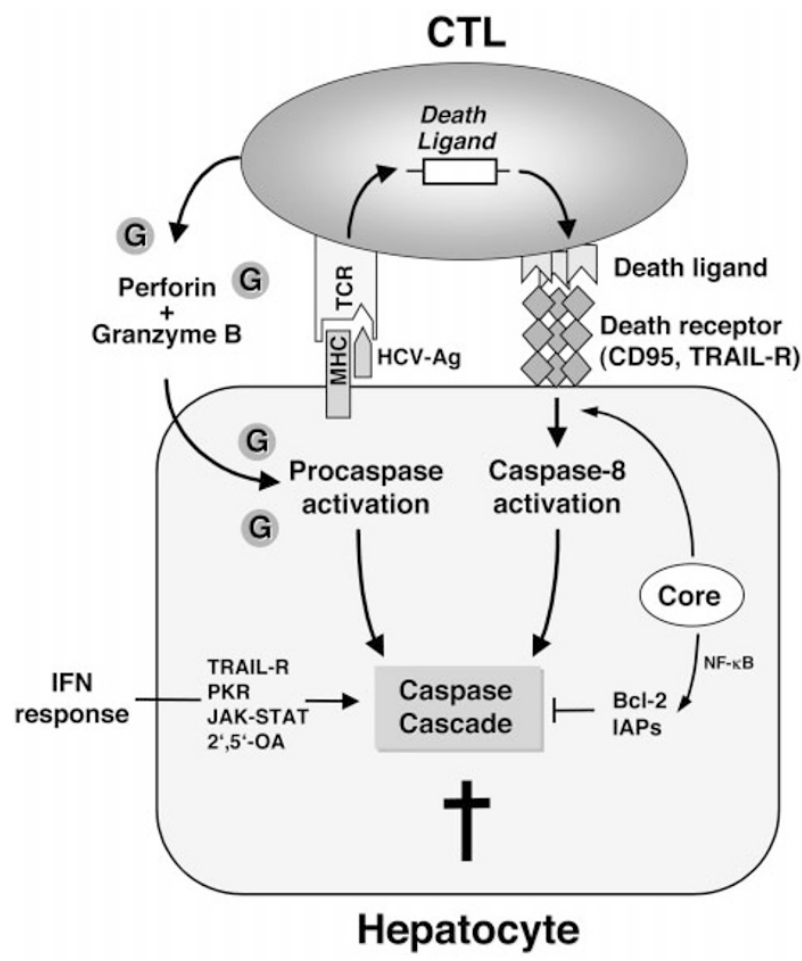

Figure 2 Mechanisms of CTL-mediated apoptosis of HCV-infected hepatocytes. Activated CTLs recognize viral antigens by the T-cell receptor (TCR) in the context of MHC antigens. TCR activation induces the expression of death ligands, such as CD95L or TRAIL, which bind to their cognate receptors, on hepatocytes and trigger caspase-8 activation. In addition, CTLs release cytoxic granules containing granzymes and perforin. Internalized granzyme B can directly activate caspase-8 and other caspases. Both mechanisms converge in a mitochondria-dependent pathway at the level of effector caspases which cleave various proteins and lead to cell death. Interferons (IFNs) produced upon viral infection may modulate apoptosis by a number of mechanisms, such as activation of JAK-STAT pathway, doublestranded RNA-dependent protein kinase (PKR), the $2^{\prime}, 5^{\prime}$ oligoadenylate system or upregulation of TRAIL and its receptors. Moreover, HCV proteins, in particular the core protein, may either positively or negatively regulate cel death. The HCV core protein has been reported to sensitize cells to death receptor-mediated apoptosis, whereas it may exert inhibitory effects through the activation of NF- $\kappa B$ and subsequent induction of antiapoptotic gene products including $\mathrm{Bcl}-\mathrm{x}_{\mathrm{L}}, \mathrm{Bcl}-2$ and inhibitor of apoptosis proteins (IAPs). The proapoptotic pathway may be involved in liver damage, whereas inhibition of apoptosis may contribute to viral persistence and development of hepatocellular carcinoma. HCV may also escape the CTL response by various other immune and antiapoptotic mechanisms

is not only accompanied by elevated CD95 expression but also by increased mRNA expression of caspases. ${ }^{71}$ In fact, several different caspases appear to be transcriptionally controlled by STAT1 ${ }^{72,73}$ As a consequence, STAT1deficient cells are largely resistant towards death ligands, while reintroduction of STAT1 can restore both the expression of caspases and apoptosis sensitivity. ${ }^{74}$ Moreover, STAT1 has been identified as a component of the TNF-R1 signaling complex, which suppresses anti-apoptotic NF- $k$ B activation. ${ }^{75}$

Additional important targets of the IFN response are the $2^{\prime}, 5^{\prime}$-oligoadenylate system, in particular RNase L, and double-stranded RNA-dependent protein kinase PKR. PKR can inhibit viral replication by delaying the translation of viral proteins through phosphorylating initiation factor elF2 $\alpha .{ }^{76}$ On the other hand, HCV and several other viruses have developed mechanisms to inhibit PKR kinase activity. PKR has also several other targets. For instance, PKR is involved in the regulation of $\mathrm{NF}-\kappa \mathrm{B}$, presumably by activating IKK kinase activity. ${ }^{77}$ As PKR has been implicated in apoptosis signaling by double-stranded RNA and NF- $\kappa$ B activation, it is plausible that PKR may induce transcription of several death-promoting molecules that harbor NF- $\kappa \mathrm{B}$ recognition motifs in their promoters. ${ }^{78}$ In this regard, CD95 and CD95L are known to be induced by NF- $\kappa$ B. ${ }^{79-81}$ A further interesting observation noted in cells expressing a dominant-negative variant of $P K R$ is that various pro-apoptotic genes such as CD95, FADD, TRADD, caspase-8, Bax and Bad are transcriptionally suppressed. ${ }^{82}$ Consequently, PKR-deficient cells were resistant to apoptosis under several conditions. ${ }^{76,82}$ Thus, IFNs can exert their caspase-activating and proapoptotic effects by a variety of signaling processes (Figure 2).

\section{Role of HCV proteins in regulating apoptotic cell death}

In addition to host immune mechanisms, direct cytopathic viral effects are currently discussed for their involvement in HCVtriggered hepatocyte death. A direct pathogenic role of HCV has been more difficult to establish, because of the lack of tissue culture systems and animal models that support robust $\mathrm{HCV}$ replication. There have been numerous studies of various HCV proteins overexpressed in cultured cells and transgenic mice, which showed multiple effects on signal transduction, growth regulation and apoptosis. However, the net outcome of all these studies is extremely confusing. The HCV genome contains a linear, positive-strand RNA molecule which encodes a single polyprotein precursor of 3011 amino acid residues. This precursor protein is cleaved by host and viral proteases to generate nine mature structural and regulatory proteins (core, E1, E2, NS2, NS3, NS4A, NS4B, NS5A, NS5B). ${ }^{83}$ The structural components include the core and the two envelope proteins $\mathrm{E} 1$ and $\mathrm{E} 2$ which latter contains the binding site for CD81, the putative HCV (co-)receptor. The non-structural proteins function as proteases (NS2, NS3), protease cofactor (NS4A), helicase (NS3) and RNA-dependent RNA polymerase (NS5B). The function and properties of the other proteins, NS4B and NS5A, are less well characterized.

Because of the presence of a putative DNA-binding motif and nuclear localization signals, a possible function of the core protein as a gene-regulatory mediator beyond its role as nucleocapsid protein has been suggested. Several studies have therefore investigated a potential role of the core protein in regulating apoptotic cell death. The HCV core protein has been demonstrated to exert both pro- and anti-apoptotic properties, which may depend on the experimental conditions, cell type or other unknown reasons. For instance, it was shown that the core protein inhibits TNF-, cisplatin- and c-Myc-induced caspase activation and apoptosis in different non-hepatic cell lines, ${ }^{84,85}$ whereas in $\mathrm{CHO}$ cells it potentiated cell death following serum withdrawal. $^{86}$ However, also in liver-derived cells 
opposite and controversial effects were observed. In transiently transfected HepG2 cells neither the core nor the E2 protein affected TNF $\alpha$ - or anti-CD95-induced apoptosis. ${ }^{87}$ In contrast, another study suggested that transient expression of the core protein alone or together with other HCV proteins inhibited CD95-mediated apoptosis. ${ }^{88}$ It was also demonstrated that HepG2 cells constitutively expressing the core protein were more prone to undergo apoptosis in response to anti-CD95. ${ }^{89} \mathrm{~A}$ similar potentiation of CD95-induced apoptosis was found in Jurkat T-cells both upon transient and stable transfection of the core protein. ${ }^{90}$

In the different studies, only a few attempts have been made in order to understand how HCV proteins could interfere with apoptosis at the molecular level. It should be stressed that most of these studies employed artificial overexpression systems that are unlikely to mimic the in vivo situation. So far, no study reported an effect of $\mathrm{HCV}$ proteins on CD95 or CD95L surface expression. However, it was demonstrated that the core protein might physically interact with the cytoplasmic domains of CD95, TNF-R1 and the lymphotoxin $\beta$ receptor, and thereby enhances downstream signaling events of these receptors. ${ }^{90,91}$ Moreover, the core protein did not only interact with death receptors but also with the death domain (DD) of FADD, but not TRADD. As a consequence, expression of the core protein enhanced FADD-mediated apoptosis and suppressed recruitment of TRADD and TRAF-2 and subsequent JNK activation in response to TNF treatment. ${ }^{92}$

The core protein has also been reported to bind to p53. However, in the different reports it either activates or inactivates p53 and its downstream target p21 Waf 93-95 Very recently, the core protein itself was found to alter mitochondrial function and induce oxidative stress. ${ }^{96}$ Upon overexpression in different cell lines, a fraction of the core protein was localized at mitochondria and was associated with increased cytochrome $c$ release, but curiously, not with altered apoptosis. There are some reports indicating that not only the core protein, but also NS3 or NS5A confers resistance to apoptotic cell death. ${ }^{97,98}$ Moreover, NS5A may play a role in repressing IFN activity. ${ }^{99}$ In this regard, genetic variability in a region of NS5A has been associated with different sensitivity of the different genotypes of HCV to IFN- $\alpha$. NS5A from IFN-resistant strains can repress the activity of PKR, a mediator of IFN-induced antiviral and apoptotic responses. ${ }^{77}$ Interestingly, resistance to IFN and development of persistent infection are major features of the most widespread HCV genotypes $1 \mathrm{~A}$ and $1 \mathrm{~B}$.

The reasons for the discrepancy between the opposite results concerning pro- and anti-apoptotic effects of $\mathrm{HCV}$ proteins remain elusive. Different experimental conditions, cell types, apoptotic stimuli and $\mathrm{HCV}$ strains might contribute to the contradicting observations. Because most cells in the studies were transfected tumor cell lines, the possibility of clonal variations even in the same line cannot be ignored. In addition, the protein expression level in the transfected cells may affect the observed effects. In most reports non-physiological overexpression has been employed, whereas the viral proteins are usually present in very low quantities in HCV-infected patients. Thus, ectopic expression of the HCV proteins in the absence of virus morphogenesis is unlikely to mimic the situation of natural infection.

To avoid potential artefacts caused by non-physiological overexpression in cell culture, $\mathrm{HCV}$ transgenic mouse models have been recently generated. In C57/BL/6 mice constitutive overexpression of the core protein sensitized cells to apoptosis triggered by anti-CD95. ${ }^{100}$ In contrast, in conditional transgenic Balb/c mice expressing core, E1, E2 and NS2 proteins liver cell apoptosis was significantly reduced and the survival rate correlated with $\mathrm{HCV}$ protein expression. ${ }^{101}$ Interestingly, activation of caspase-9, but not of caspase-8 was inhibited in liver tissue by HCV proteins. Moreover, cytochrome $c$ release from mitochondria was blocked in $\mathrm{HCV}$ expressing mice suggesting that HCV proteins interfered with the mitochondrial death pathway. The contribution of individual viral proteins to the inhibition of CD95-mediated apoptosis was not investigated. Nevertheless, this and other data suggest that HCV proteins might directly or indirectly inhibit death receptor-mediated apoptosis rather than facilitating apoptosis.

\section{T-cell apoptosis potentially involved in sustained $\mathrm{HCV}$ infection}

$\mathrm{HCV}$ infection is characterized by a high tendency towards chronicity. As mentioned above, acutely infected subjects show a T-cell response often against a single viral antigen, whereas only individuals who resolve HCV infection have a strong, rapid and persistent CTL response that is directed against multiple HCV epitopes. Thus, the dominant cause of viral persistence might be the development of a weak immune response to viral antigens with a corresponding inability to eradicate HCV-infected cells. Chronic infection is characterized by low frequencies of $\mathrm{CD}^{+} \mathrm{T}$-cells in peripheral blood, but they are not necessarily absent from the liver. ${ }^{102}$ Survival of $\mathrm{HCV}$ in the liver infiltrated with virus-specific CTLs might be explained by a defect in cytotoxic activity or production of cytokines that limit HCV replication. The failure to eliminate virus-infected cells appears surprising, because the expression of HLA and adhesion molecules as well as of CD95 is upregulated in liver during $\mathrm{HCV}$ infection, which should facilitate antigen recognition, CTL-hepatocyte interaction and hepatocytolysis. Results obtained by several groups show an inverse correlation between levels of antiviral CTL activity and viral load, suggesting that the virus is controllable, at least to some extent, by CTLs. ${ }^{18,103,104}$ Moreover, the virus-specific immune response may not only target infected cells, but also noninfected hepatocytes via the release of soluble proapoptotic mediators, such as CD95L and TNF. ${ }^{29}$ Nonetheless, for some reasons $\mathrm{HCV}$ is rarely eliminated despite the principal presence of an immune response.

Recent studies showed that HCV might escape innate and adaptive immune responses by several mechanisms. A correlation between circulating HLA class I antigen levels and HCV disease activity suggested that these antigens might play a role in the insufficient cytotoxic response. In fact, HLA-I molecules containing viral peptides within the antigen-binding site are released from cell membrane in their heterodimeric configuration. These soluble factors 
might interact with virus-specific CTLs and negatively influence the CTL response. ${ }^{105}$ In addition to the aforementioned inhibition of the IFN response by NS5A, it was shown that the core protein inhibits T-cell proliferation in vivo, and IL-2 and IFN- $\gamma$ production in vitro through binding to the complement $\mathrm{C} 1 \mathrm{q}$ receptor. ${ }^{106}$ Furthermore, binding of HCV envelope protein E2 to CD81 inhibits NK cell functions and IFN production. ${ }^{107}$ Finally, at least part of the explanation of the HCVs evasiveness lies in the mutability of its RNA genome causing it to exist as a mixture of related species (quasispecies) that evolve under immune selection. $^{19}$

In addition, T-cell apoptosis in patients with chronic HCV infection is considered to contribute to virus persistence. ${ }^{108,109}$ It was demonstrated that enhanced apoptosis of activated peripheral T-cells in patients with chronic HCV infection is due to decreased expression of $\mathrm{NF}-\kappa \mathrm{B}$ in the nucleus of those cells. ${ }^{110}$ Since NF- $\mathrm{B}$ plays a crucial role in cell proliferation as well as in the immune response, especially in the T-cell compartment, decreased NF- $\kappa \mathrm{B}$ activity might contribute to an inappropriate immune response. Deletion of T-cells via apoptosis normally occurs as a physiological mechanism in order to down-size the immune response. This activation-induced cell death (AICD) might also serve as a second line of defence against autoimmunity by deleting autoreactive cells in the periphery. T-cell activation leads to the expression of CD95L and permits their elimination by a fratricide or suicide mechanism. A recently published study suggested that HCV infection induces CD95 expression on PBMCs, and that soluble CD95L leads to accelerated apoptosis of these CD95-expressing cells. ${ }^{111}$ However, whether an increased number of T-cells undergo AICD in vivo during $\mathrm{HCV}$ infection remains speculative. It has been suggested that the CD95/CD95L system plays an important role for the initiation of AICD, whereas the TNF system is more apparent at later phases. ${ }^{112}$ Finally, it appears that also hepatocytes can be induced to express CD95L during an inflammatory response. ${ }^{113}$ CD95L-positive hepatocytes might delete HCV-specific CTLs and thereby promote chronic infection. Thus, a variety of immune and signaling processes could lead to apoptosis of activated T-cells and contribute to sustained HCV infection.

\section{Anti-apoptotic mechanisms involved in liver cirrhosis and hepatocellular carcinoma of chronic HCV infection}

$\mathrm{HCV}$ is the major causative agent for liver cirrhosis and hepatocellular carcinoma. The long latency period of hepatocellular carcinoma suggests that tumor development requires multiple events. In vitro, at least four HCV proteins, core, NS3, NS4B and NS5A, have been shown to be able to transform cells either alone or in combination with each other or the Ras oncogene. Two independently derived transgenic mouse lines expressing either only the core protein or all structural proteins have been found to develop steatosis and subsequent hepatocellular carcinoma in a considerable percentage of the animals. ${ }^{114,115}$ Steatosis, characterized by fat droplets of various size in the cytoplasm, is a frequently occurring feature of $\mathrm{HCV}$ infection. The transgenic mice displayed increased lipid peroxidation and mitochondrial DNA damage. Remarkably, oxidative stress was even observed in the absence of leukocyte infiltration. It was therefore suggested that carcinogenesis in core transgenic mice and potentially in HCV-infected individuals might be attributable to the generation of oxygen radicals in the liver and subsequent DNA damage. Studies in cultured cells have confirmed a role for the core protein in induction of oxidative stress, potentially through a direct interaction with mitochondria. ${ }^{96}$ This data strongly suggests that $\mathrm{HCV}$ proteins have transforming potential and can induce hepatocellular carcinoma formation, at least under experimental conditions.

The long latency of hepatocellular carcinoma indicates that, in addition to a direct oncogenic and genotoxic potential of $\mathrm{HCV}$ proteins, other events such as disturbances in apoptosis must occur during tumor development. Indeed, previous studies revealed a complete or partial loss of CD95 expression in hepatocellular carcinoma. ${ }^{116}$ This implies a reduced susceptibility towards T-cell cytotoxicity. Moreover, hepatocellular carcinomas upregulate CD95L expression, ${ }^{117}$ which could lead to cell death of CTLs and the establishment of an immune-privileged environment. Among the different $\mathrm{HCV}$ proteins the core protein has certainly the greatest effects on cellular functions. At first view, the observation that the core protein potentiates and inhibits apoptosis is confusing, but nevertheless may be biologically relevant. The promotion of apoptosis may explain the occurrence of hepatitis and liver damage. Inhibition of apoptosis by the core protein, on the other hand, may allow the virus to establish persistent infection and contribute to the development of hepatocellular carcinoma.

Various studies suggest that activation of the transcription factor $\mathrm{NF}-\kappa \mathrm{B}$ is important for the development of an anti-apoptotic phenotype. For example, hepatoma cells expressing HCV proteins became resistant to CD95induced apoptosis and showed increased NF- $\kappa$ B activity. ${ }^{88}$ Similarly, the core protein potently activated $N F-\kappa B$ and AP1 and conferred resistance to TNF, while NF- $\kappa \mathrm{B}$ inhibition sensitized hepatocytes to TNF-induced apoptosis. ${ }^{118-120}$ It should be noted that other studies found no effects, or even demonstrated a reduced NF- $\kappa \mathrm{B}$ activity in core-expressing cells. ${ }^{91,121,122}$ Interestingly, it was demonstrated that NF- $\kappa \mathrm{B}$ activation is upregulated not only in core-transfected hepatoma cells, but also in HCV-infected liver tissue. ${ }^{119}$ The anti-apoptotic effect of the core protein might be due to the activation of $\mathrm{NF}-\kappa \mathrm{B}$ and may be advantageous for $\mathrm{HCV}$ by allowing hepatocytes to survive, resulting in sustained infection. The increased activation of NF- $\kappa \mathrm{B}$ apparently correlates inversely with the apoptotic index but not with the viral load. ${ }^{123}$ Thus, presumably not only viral proteins but also host factors such as different cytokines that are upregulated in chronic HCV infection influence NF- $\kappa \mathrm{B}$ activity. It is also plausible that oxidative stress induced by the core protein might trigger activation of the transcription factor.

Deletion of the NF- $\kappa \mathrm{B}$ subunit RelA is lethal during embryonic development of mice because of massive hepatocyte apoptosis. ${ }^{124} \mathrm{NF}-\kappa \mathrm{B}$ activation also appears to 
prime adult hepatocytes for proliferation in response to partial hepatectomy. ${ }^{125}$ Some evidence was provided that increased expression of RelA is associated not only with decreased apoptosis, but also with reduced fibrosis, suggesting that RelA expression may protect against liver fibrosis and hepatocellular damage. ${ }^{123}$ Another study showed that with increasing fibrosis and cirrhosis the antiapoptotic molecule $\mathrm{Bcl}-2$ is upregulated, which might explain the high incidence of hepatocellular carcinoma in patients with cirrhosis. ${ }^{126}$ In this respect, NF- $\kappa$ B upregulates anti-apoptotic genes encoding for C-FLIP and different members of the Bcl-2 and IAP family. Moreover, NF- $\kappa \mathrm{B}$ is not only pro-inflammatory and anti-apoptotic, but is also required for proliferation and cell cycle progression. If the core protein does indeed activate $\mathrm{NF}-\kappa \mathrm{B}$ and prevent apoptosis under natural $\mathrm{HCV}$ infection, this pathway may provide an attractive target for development of anti-HCV drugs. Altogether, the importance of different viral and host factors for carcinoma formation is still unclear. Presumably, the recently established transgenic mouse strains will be most instrumental for dissecting the transforming potential of different HCV proteins, the induction of genotoxic stress, and the role of $\mathrm{NF}-\kappa \mathrm{B}$ and apoptosis inhibition in development of hepatocellular carcinoma.

\section{Conclusions}

A variety of apoptotic mechanisms might play a role in the elimination of infected cells, the immune response and inflammatory liver injury. However, the reasons why cell killing is not sufficient to eradicate $\mathrm{HCV}$ infection remain unclear. One explanation could be the overwhelming rates of viral replication and spread relative to the ability of the immune system to target enough CTLs to destroy all of the infected cells. Alternatively, if clearance of HCV from the liver results mainly from the antiviral effect of T-cell-derived cytokines, chronic HCV infection could occur, if HCV is not sensitive to such cytokines or if insufficient quantities of cytokines are produced. Production of inappropriate antiviral factors of the infected cells as well as viral proteins that inhibit the antiviral activity of IFNs and other cytokines might further contribute to the lack of viral clearance. Furthermore, in chronic HCV infection, there is an extensive evolution of quasispecies that can coexist with a multispecific CTL response. Since HCV proteins can also infect immune cells, the possible expression of $\mathrm{HCV}$ peptides may induce a CTL-mediated immune suppression and ineffective viral clearance. Several arguments underscore the relevance of immune-mediated liver cell damage in $\mathrm{HCV}$ infection. Liver damage coincides with the development of a host immune response and not with viral replication. Conversely, chronic viral replication often occurs without evidence of liver cell damage. Finally, it is conceivable that dysregulation of $\mathrm{NF}-\kappa \mathrm{B}$ signalling results in a survival advantage of HCV-infected cells, permitting the virus to persist in long-lived cellular compartments. Increased activation of $\mathrm{NF}-\kappa \mathrm{B}$ during chronic $\mathrm{HCV}$-infection might contribute to the up-regulation of anti-apoptotic molecules with increased risk of development hepatocellular carcinoma. Concerning a functional role of apoptosis in $\mathrm{HCV}$ infection, several important aspects are still unknown including the kinetics and extent of apoptotic processes, the expression of proapoptotic mediators during acute and chronic phases of infection, as well as a potential link to virus persistence.

Most findings about the pathogenicity of $\mathrm{HCV}$ and involvement of apoptosis have been obtained in cell culture systems, because adequate tissue culture and animal models were not available. Therefore, interpretation of these data remains restricted. The recent success of isolating a cDNA clone capable of generating infectious RNA transcripts may be an important step towards the development of a tissue culture system. ${ }^{127,128}$ At present, the most effective model for studying HCV replication is the replicon system. ${ }^{129}$ Recently, a mouse model has been described which allowed replication of $\mathrm{HCV}$ in chimeric human livers that were transplanted into SCID mice. ${ }^{130}$ Since this system lacks an immunological component, it may find its greatest utility in the evaluation of the new antiviral drugs, although adoptive transfer of human T-cells should be feasible. So far, the chimpanzee is the only animal model that faithfully reflects most features of human $\mathrm{HCV}$ infection. However, due to the enormous costs and other aspects, studying apoptotic mechanisms in this animal model remains very limited.

\section{References}

1. Alter MJ (1997) Epidemiology of hepatitis C. Hepatology 26: $62 S-65 S$

2. Okuda M, Hino K, Korenaga M, Yamaguchi Y, Katoh Y and Okita K (1999) Differences in hypervariable region 1 quasispecies of hepatitis $C$ virus in human serum, peripheral blood mononuclear cells, and liver. Hepatology 29:217-222

3. Muratori L, Gibellini D, Lenzi M, Cataleta M, Muratori P, Morelli MC and Bianchi FB (1996) Quantification of hepatitis C virus-infected peripheral blood mononuclear cells by in situ reverse transcriptase-polymerase chain reaction. Blood 88: 2768-2774

4. Radkowski M, Kubicka J, Kisiel E, Cianciara J, Nowicki M, Rakela J and Laskus $\mathrm{T}$ (2000) Detection of active hepatitis $C$ virus and hepatitis $\mathrm{G}$ virus/GB virus $C$ replication in bone marrow in human subjects. Blood 95: 3986-3989

5. Agnello V, Abel G, Knight GB and Muchmore E (1998) Detection of widespread hepatocyte infection in chronic hepatitis $C$. Hepatology 28: 573-584

6. Kerr JF (1971) Shrinkage necrosis: a distinct mode of cellular death. J. Pathol. 105: $13-20$

7. Watanabe-Fukunaga R, Brannan Cl, Copeland NG, Jenkins NA and Nagata S (1992) Lymphoproliferation disorder in mice explained by defects in Fas antigen that mediates apoptosis. Nature 356: 314-317

8. Takahashi T, Tanaka M, Brannan Cl, Jenkins NA, Copeland NG, Suda T and Nagata S (1994) Generalized lymphoproliferative disease in mice, caused by a point mutation in the Fas ligand. Cell 76: 969-976

9. Ogasawara J, Watanabe-Fukunaga R, Adachi M, Matsuzawa A, Kasugai T, Kitamura Y, Itoh N, Suda T and Nagata S (1993) Lethal effect of the anti-Fas antibody in mice. Nature 364: 806-809

10. Tanaka M, Suda T, Yatomi T, Nakamura N and Nagata S (1997) Lethal effect of recombinant human Fas ligand in mice pretreated with Propionibacterium acnes. J. Immunol. 158: 2303-2309

11. Hayashi J, Kishihara Y, Yamaji K, Furusyo N, Yamamoto T, Pae Y, Etoh Y, Ikematsu $H$ and Kashiwagi S (1997) Hepatitis $C$ viral quasispecies and liver damage in patients with chronic hepatitis $\mathrm{C}$ virus infection. Hepatology 25: 697-701

12. Hiramatsu N, Hayashi N, Katayama K, Mochizuki K, Kawanishi Y, Kasahara A Fusamoto H and Kamada T (1994) Immunohistochemical detection of Fas antigen in liver tissue of patients with chronic hepatitis C. Hepatology 19: 13541359

13. Okazaki M, Hino K, Fujil K, Kobayashi N and Okita K (1996) Hepatic Fas antigen expression before and after interferon therapy in patients with chronic hepatitis C. Dig. Dis. Sci. $41: 2453-2458$ 
14. Mita E, Hayashi N, lio S, Takehara T, Hijioka T, Kasahara A, Fusamoto H and Kamada T (1994) Role of Fas ligand in apoptosis induced by hepatitis $C$ virus infection. Biochem. Biophys. Res. Commun. 204: 468-474

15. Ferenbach DA, Haydon GH, Rae F, Malcomson RD and Harrison DJ (1997) Alteration in mRNA levels of Fas splice variants in hepatitis C-infected liver. J. Pathol. 183: 299-304

16. Pianko S, Patella S, Ostapowicz G, Desmond P and Sievert W (2001) Fasmediated hepatocyte apoptosis is increased by hepatitis $C$ virus infection and alcohol consumption, and may be associated with hepatic fibrosis: mechanisms of liver cell injury in chronic hepatitis $C$ virus infection. J. Viral Hepat. 8: 406-413

17 lio S, Hayashi N, Mita E, Ueda K, Mochizuki K, Hiramatsu N, Kanto T, Sasaki Y, Kasahara A and Hori M (1998) Serum levels of soluble Fas antigen in chronic hepatitis $C$ patients. J. Hepatol. 29: 517-523

18. Nelson DR, Marousis CG, Davis GL, Rice CM, Wong J, Houghton M and Lau JY (1997) The role of hepatitis C virus-specific cytotoxic T lymphocytes in chronic hepatitis C. J. Immunol. 158: 1473-1481

19. Erickson AL, Kimura Y, Igarashi S, Eichelberger J, Houghton M, Sidney J, McKinney D, Sette A, Hughes AL and Walker CM (2001) The outcome of hepatitis $C$ virus infection is predicted by escape mutations in epitopes targeted by cytotoxic T lymphocytes. Immunity 15: 883-895

20. Lechner F, Wong DKH, Dunbar PR, Chapman R, Chung RT, Dohrenwend P, Robbins G, Phillips R, Klenerman P and Walker BD (2000) Analysis of successful immune responses in persons infected with hepatitis $C$ virus. J. Exp. Med. 191: $1499-1512$

21. Thimme R, Oldach D, Chang KM, Steiger C, Ray SC and Chisari FV (2001) Determinants of viral clearance and persistence during acute hepatitis $C$ virus infection. J. Exp. Med. 194: 1395-1406

22. McGuinness PH, Bishop GA, Painter DM, Chan R and McCaughan GW (1996) Intrahepatic hepatitis $C$ RNA levels do not correlate with degree of liver injury in patients with chronic hepatitis C. Hepatology 23: 676-687

23. Rodriguez-Inigo E, Bartolome J, de Lucas S, Manzarbeitia F, Pardo M, Arocena C, Gosalvez J, Oliva H and Carreno V (1999) Histological damage in chronic hepatitis $C$ is not related to the extent of infection in the liver. Am. J. Pathol. 154: $1877-1881$

24. Calabrese F, Pontisso P, Pettenazzo E, Benvegnu L, Vario A, Chemello L, Alberti A and Valente M (2000) Liver cell apoptosis in chronic hepatitis $C$ correlates with histological but not biochemical activity or serum HCV-RNA levels. Hepatology 31: 1153-1159

25. Nuti S, Rosa D, Valiante NM, Saletti G, Caratozzolo M, Dellabona P, Barnaba V and Abrignani S (1998) Dynamics of intra-hepatic lymphocytes in chronic hepatitis C: enrichment for Valpha24+ T cells and rapid elimination of effector cells by apoptosis. Eur. J. Immunol. 28: 3448-3455

26. Muschen M, Warskulat U, Peters-Regehr T, Bode JG, Kubitz R and Haussinger D (1999) Involvement of CD95 (Apo-1/Fas) ligand expressed by rat Kupffer cells in hepatic immunoregulation. Gastroenterology 116: 666-677

27. Miwa K, Asano M, Horai R, Iwakura Y, Nagata S and Suda T (1998) Caspase 1. independent IL-1beta release and inflammation induced by the apoptosis inducer Fas ligand. Nat. Med. 4: 1287-1292

28. Gonzalez-Amaro R, Garcia-Monzon C, Garcia-Buey L, Moreno-Otero R, Alonso JL, Yague E, Pivel JP, Lopez-Cabrera M, Fernandez-Ruiz E and Sanchez-Madrid F (1994) Induction of tumor necrosis factor alpha production by human hepatocytes in chronic viral hepatitis. J. Exp. Med. 179: 841-848

29. Ando K, Hiroishi K, Kaneko T, Moriyama T, Muto Y, Kayagaki N, Yagita H, Okumura K and Imawari M (1997) Perforin, Fas/Fas ligand, and TNF-alpha pathways as specific and bystander killing mechanisms of hepatitis $C$ virusspecific human CTL. J. Immunol. 158: 5283-5291

30. Koziel MJ, Dudley D, Afdhal N, Grakoui A, Rice CM, Choo QL, Houghton M and Walker BD (1995) HLA class I-restricted cytotoxic T lymphocytes specific for hepatitis $C$ virus. Identification of multiple epitopes and characterization of patterns of cytokine release. J. Clin. Invest. 96: 2311-2321

31. Tokushige $\mathrm{K}$, Yamaguchi $\mathrm{N}$, Ikeda I, Hashimoto E, Yamauchi K and Hayashi $\mathrm{N}$ (2000) Significance of soluble TNF receptor-l in acute-type fulminant hepatitis. Am. J. Gastroenterol. 95: 2040-2046

32. Leist M, Gantner F, Bohlinger I, Tiegs G, Germann PG and Wendel A (1995) Tumor necrosis factor-induced hepatocyte apoptosis precedes liver failure in experimental murine shock models. Am. J. Pathol. 146: 1220-1234
33. Jaeschke H, Fisher MA, Lawson JA, Simmons CA, Farhood A and Jones DA (1998) Activation of caspase 3 (CPP32)-like proteases is essential for TNFalpha-induced hepatic parenchymal cell apoptosis and neutrophil-mediated necrosis in a murine endotoxin shock model. J. Immunol. 160: 3480-3486

34. Gantner F, Leist M, Lohse AW, Germann PG and Tiegs G (1995) Concanavalin A-induced T-cell-mediated hepatic injury in mice: the role of tumor necrosis factor. Hepatology 21: 190-198

35. Kunstle G, Hentze H, Germann PG, Tiegs G, Meergans T and Wendel A (1999) Concanavalin $A$ hepatotoxicity in mice: tumor necrosis factor-mediated organ failure independent of caspase-3-like protease activation. Hepatology 30 : $1241-1251$

36. Sedger LM, Shows DM, Blanton RA, Peschon JJ, Goodwin RG, Cosman D and Wiley SR (1999) IFN-gamma mediates a novel antiviral activity through dynamic modulation of TRAIL and TRAIL receptor expression. J. Immunol. 163: 920-926

37. Strater J, Walczak H, Pukrop T, Von Muller L, Hasel C, Kornmann M, Mertens T and Moller P (2002) TRAIL and its receptors in the colonic epithelium: a putative role in the defense of viral infections. Gastroenterology 122: 659-666

38. Zhang M, Li X, Pang X, Ding L, Clouse K, Hewlett I and Dayton Al (2001) Identification of a potential HIV-induced source of bystander-mediated apoptosis in T cells: upregulation of TRAIL in primary human macrophages by HIV-1 TAT. J. Biomed. Sci. 8: 291-296

39. Sato K, Hida S, Takayanagi H, Yokochi T, Kayagaki N, Takeda K, Yagita H, Okumura K, Tanaka N, Taniguchi T and Ogasawara K (2001) Antiviral response by natural killer cells through TRAIL gene induction by IFN-alpha/beta. Eur. J. Immunol. 31: 3138-3146

40. Griffith TS, Wiley SR, Kubin MZ, Sedger LM, Maliszewski CR and Fanger NA (1999) Monocyte-mediated tumoricidal activity via the tumor necrosis factorrelated cytokine, TRAIL. J. Exp. Med. 189: 1343-1354

41. Kayagaki N, Yamaguchi N, Nakayama M, Eto H, Okumura $\mathrm{K}$ and Yagita $\mathrm{H}$ (1999) Type I interferons (IFNs) regulate tumor necrosis factor-related apoptosis-inducing ligand (TRAIL) expression on human T cells: A novel mechanism for the antitumor effects of type I IFNs. J. Exp. Med. 189: 1451 1460

42. Raftery MJ, Schwab M, Eibert SM, Samstag Y, Walczak H and Schonrich G (2001) Targeting the function of mature dendritic cells by human cytomegalovirus: a multilayered viral defense strategy. Immunity 15: 9951009

43. Shin EC, Ahn JM, Kim CH, Choi Y, Ahn YS, Kim H, Kim SJ and Park JH (2001) IFN-gamma induces cell death in human hepatoma cells through a TRAIL/ death receptor-mediated apoptotic pathway. Int. J. Cancer 93: 262-268

44. Walczak H, Miller RE, Ariail K, Gliniak B, Griffith TS, Kubin M, Chin W, Jones J, Woodward A, Le T, Smith C, Smolak P, Goodwin RG, Rauch CT, Schuh JC and Lynch DH (1999) Tumoricidal activity of tumor necrosis factor-related apoptosis-inducing ligand in vivo. Nat. Med. 5: 157-163

45. Jo M, H. KT, Seol DW, Esplen JE, Dorko K, Billiar TR and Strom SC (2000) Apoptosis induced in normal human hepatocytes by tumor necrosis factorrelated apoptosis-inducing ligand. Nat. Med. 6: 564-567

46. Lawrence D, Shahrokh Z, Marsters S, Achilles K, Shih D, Mounho B, Hillan K, Totpal K, DeForge L, Schow P, Hooley J, Sherwood S, Pai R, Leung S, Khan L, Gliniak B, Bussiere J, Smith CA, Strom SS, Kelley S, Fox JA, Thomas D and Ashkenazi A (2001) Differential hepatocyte toxicity of recombinant Apo2L/ TRAIL versions. Nat. Med. 7: 383-385

47. Ichikawa K, Liu W, Zhao L, Wang Z, Liu D, Ohtsuka T, Zhang H, Mountz JD, Koopman WJ, Kimberly RP and Zhou T (2001) Tumoricidal activity of a novel anti-human DR5 monoclonal antibody without hepatocyte cytotoxicity. Nat. Med. 7: 954-960

48. Chandler JM, Cohen GM and MacFarlane M (1998) Different subcellular distribution of caspase-3 and caspase-7 following Fas-induced apoptosis in mouse liver. J. Biol. Chem. 273: 10815-10818

49. Van Molle W, Denecker G, Rodriguez I, Brouckaert P, Vandenabeele P and Libert C (1999) Activation of caspases in lethal experimental hepatitis and prevention by acute phase proteins. J. Immunol. 163: 5235-5241

50. Kunstle G, Leist M, Uhlig S, Revesz L, Feifel R, MacKenzie A and Wendel A (1997) ICE-protease inhibitors block murine liver injury and apoptosis caused by CD95 or by TNF-alpha. Immunol Lett. $55: 5-10$ 
51. Rouquet N, Pages JC, Molina T, Briand P and Joulin V (1996) ICE inhibitor YVADcmk is a potent therapeutic agent against in vivo liver apoptosis. Curr. Biol. 6: 1192-1195

52. Bantel H, Ruck P, Gregor Mand Schulze-Osthoff K (2001) Detection of elevated caspase activation and early apoptosis in liver diseases. Eur. J. Cell Biol. 80: 230-239

53. Bantel H, Ruck $P$ and Schulze-Osthoff $\mathrm{K}$ (2000) In situ monitoring of caspase activation in hepatobiliary diseases. Cell Death Differ. 7: 504-505

54. Bantel H, Lugering A, Poremba C, Lugering N, Held J, Domschke W and Schulze-Osthoff K (2001) Caspase activation correlates with the degree of inflammatory liver injury in chronic hepatitis $\mathrm{C}$ virus infection. Hepatology 34 : $758-767$

55. Kronenberger B, Ruster B, Lee JH, Sarrazin C, Roth WK, Herrmann G and Zeuzem S (2000) Hepatocellular proliferation in patients with chronic hepatitis $\mathrm{C}$ and persistently normal or abnormal aminotransferase levels. J. Hepatol. 33 : 640-647

56. Schulze-Osthoff K, Walczak H, Droge W and Krammer PH (1994) Cell nucleus and DNA fragmentation are not required for apoptosis. J. Cell Biol. 127: 15-20

57. Grasl-Kraupp B, Ruttkay-Nedecky B, Koudelka H, Bukowska K, Bursch W and Schulte-Hermann R (1995) In situ detection of fragmented DNA (TUNEL assay) fails to discriminate among apoptosis, necrosis, and autolytic cell death: a cautionary note. Hepatology 21: 1465-1468

58. Lawson JA, Fisher MA, Simmons CA, Farhood A and Jaeschke H (1998) Parenchymal cell apoptosis as a signal for sinusoidal sequestration and transendothelial migration of neutrophils in murine models of endotoxin and Fas-antibody-induced liver injury. Hepatology 28: 761-767

59. Faouzi S, Burckhardt BE, Hanson JC, Campe CB, Schrum LW and Maher JJ (2001) Anti-Fas induces hepatic chemokines and promotes inflammation by an NF-kappa B-independent, caspase-3-dependent pathway. J. Biol. Chem. 276: 4977-4982

60. Neumann AU, Lam NP, Dahari H, Gretch DR, Wiley TE, Layden TJ and Perelson AS (1998) Hepatitis C viral dynamics in vivo and the antiviral efficacy of interferon-alpha therapy. Science 282: 103-107

61. Zeuzem S, Schmidt JM, Lee JH, von Wagner M, Teuber G and Roth WK (1998) Hepatitis $C$ virus dynamics in vivo: effect of ribavirin and interferon alfa on viral turnover. Hepatology 28: 245-252

62. Gholson CF, Morgan K, Catinis G, Favrot D, Taylor B, Gonzalez E and Balart L (1997) Chronic hepatitis C with normal aminotransferase levels: a clinical histologic study. Am. J. Gastroenterol. 92: 1788-1792

63. Schulze-Osthoff K, Ferrari D, Los M, Wesselborg S and Peter ME (1998) Apoptosis signaling by death receptors. Eur. J. Biochem. 254: 439-459

64. Rodriguez I, Matsuura K, Ody C, Nagata S and Vassalli P (1996) Systemic injection of a tripeptide inhibits the intracellular activation of CPP32-like proteases in vivo and fully protects mice against Fas-mediated fulminant liver destruction and death. J. Exp. Med. 184: 2067-2072

65. Jones RA, Johnson VL, Buck NR, Dobrota M, Hinton RH, Chow SC and Kass GE (1998) Fas-mediated apoptosis in mouse hepatocytes involves the processing and activation of caspases. Hepatology 27: 1632-1642

66. Medema JP, Toes RE, Scaffidi C, Zheng TS, Flavell RA, Melief CJ, Peter ME, Offringa R and Krammer PH (1997) Cleavage of FLICE (caspase-8) by granzyme B during cytotoxic Tlymphocyte-induced apoptosis. Eur. J. Immunol. 27: $3492-3498$

67. Sarin A, Haddad EK and Henkart PA (1998) Caspase dependence of target cell damage induced by cytotoxic lymphocytes. J. Immunol. 161: 2810-2816

68. Lacronique V, Mignon A, Fabre M, Viollet B, Rouquet N, Molina T, Porteu A, Henrion A, Bouscary D, Varlet P, Joulin V and Kahn A (1996) Bcl-2 protects from lethal hepatic apoptosis induced by an anti-Fas antibody in mice. Nat. Med. 2: $80-86$

69. Feldmann G, Haouzi D, Moreau A, Durand-Schneider AM, Bringuier A, Berson A, Mansouri A, Fau D and Pessayre D (2000) Opening of the mitochondrial permeability transition pore causes matrix expansion and outer membrane rupture in Fas-mediated hepatic apoptosis in mice. Hepatology 31: 674-683

70. Yin XM, Wang K, Gross A, Zhao Y, Zinkel S, Klocke B, Roth KA and Korsmeyer SJ (1999) Bid-deficient mice are resistant to Fas-induced hepatocellular apoptosis. Nature 400: $886-891$

71. Dai C and Krantz SB (1999) Interferon gamma induces upregulation and activation of caspases 1,3 , and 8 to produce apoptosis in human erythroid progenitor cells. Blood 93: 3309-3316
72. Chin YE, Kitagawa M, Kuida K, Flavell RA and Fu XY (1997) Activation of the STAT signaling pathway can cause expression of caspase 1 and apoptosis. Mol. Cell Biol. 17: 5328-5337

73. Fulda S and Debatin KM (2002) IFNgamma sensitizes for apoptosis by upregulating caspase-8 expression through the Stat1 pathway. Oncogene 21: 2295-2308

74. Kumar A, Commane M, Flickinger TW, Horvath CM and Stark GR (1997) Defective TNF-alpha-induced apoptosis in STAT1-null cells due to low constitutive levels of caspases. Science 278: 1630-1632

75. Wang Y, Wu TR, Welte T and Chin YE (2000) Stat1 as a component of tumor necrosis factor alpha receptor 1-TRADD signaling complex to inhibit NFkappaB activation. Mol. Cell Biol. 20: 455-412

76. Balachandran S, Roberts PC, Brown LE, Truong H, Pattnaik AK, Archer DR and Barber GN (2000) Essential role for the dsRNA-dependent protein kinase PKR in innate immunity to viral infection. Immunity 13: $129-141$

77. Gale Jr MJ, Korth MJ, Tang NM, Tan SL, Hopkins DA, Dever TE, Polyak SJ, Gretch DR and Katze MG (1997) Evidence that hepatitis C virus resistance to interferon is mediated through repression of the PKR protein kinase by the nonstructural 5A protein. Virology 230: 217-227

78. Barber GN (2001) Host defense, viruses and apoptosis. Cell Death Differ. 8: $113-126$

79. BauerMK, VogtM, Los M, SiegelJ, Wesselborg Sand Schulze-Osthoff K(1998) Role of reactive oxygen intermediates in activation-induced CD95 (APO-1/Fas) ligand expression. J. Biol. Chem. 273: 8048-8055

80. Chan H, Bartos DP and Owen-Schaub LB (1999) Activation-dependent transcriptional regulation of the human Fas promoter requires NF-kappaB p50p65 recruitment. Mol. Cell Biol. 19: 2098-2108

81. Kuhnel F, Zender L, Paul Y, Tietze MK, Trautwein C, Manns M and Kubicka S (2000) NFkappaB mediates apoptosis through transcriptional activation of Fas (CD95) in adenoviral hepatitis. J. Biol. Chem. 275: 6421-6427

82. Balachandran S, Kim CN, Yeh WC, Mak TW, Bhalla K and Barber GN (1998) Activation of the dsRNA-dependent protein kinase, PKR, induces apoptosis through FADD-mediated death signaling. EMBO J. 17: 6888-6902

83. DeFrancesco R(1999) Molecular virology of the hepatitis C virus. J. Hepatol. 31 (Suppl. 1): $47-53$

84. Ray RB, Meyer K and Ray R (1996) Suppression of apoptotic cell death by hepatitis $C$ virus core protein. Virology 226: $176-182$

85. Ray RB, Meyer K, Steele R, Shrivastava A, Aggarwal BB and Ray R (1998) Inhibition of tumor necrosis factor (TNF-alpha)-mediated apoptosis by hepatitis C virus core protein. J. Biol. Chem. 273: 2256-2259

86. Honda M, Kaneko S, Shimazaki T, Matsushita E, Kobayashi K, Ping LH, Zhang HC and Lemon SM (2000) Hepatitis C virus core protein induces apoptosis and impairs cell-cycle regulation in stably transformed Chinese hamster ovary cells. Hepatology 31: 1351-1359

87. Dumoulin FL, von dem Bussche A, Sohne J, Sauerbruch T and Spengler U (1999) Hepatitis C virus core protein does not inhibit apoptosis in human hepatoma cells. Eur. J. Clin. Invest. 29: 940-946

88. Marusawa H, Hijikata M, Chiba T and Shimotohno K (1999) Hepatitis C virus core protein inhibits Fas- and tumor necrosis factor alpha-mediated apoptosis via NF-kappaB activation. J. Virol. 73: $4713-4720$

89. Ruggieri A, Harada T, Matsuura Y and Miyamura T (1997) Sensitization to Fasmediated apoptosis by hepatitis $C$ virus core protein. Virology 229: 68-76

90. Hahn CS, Cho YG, Khan BS, Lester IM and Hahn YS (2000) The HCV core protein acts as a positive regulator of Fas-mediated apoptosis in a human lymphoblastoid T cell line. Virology 266: 127-137

91. Zhu N, Khoshnan A, Schneider R, Matsumoto M, DennertG, Ware Cand Lai MM (1998) Hepatitis $C$ virus core protein binds to the cytoplasmic domain of tumor necrosis factor (TNF) receptor 1 and enhances TNF-induced apoptosis. J. Virol. 72: $3691-3697$

92. Zhu N, Ware CF and Lai MM (2001) Hepatitis C virus core protein enhances FADD-mediated apoptosis and suppresses TRADD signaling of tumor necrosis factor receptor. Virology 283: 178-187

93. Lu W, Lo SY, Chen M, Wu K, Fung YK and Ou JH (1999) Activation of p53 tumor suppressor by hepatitis $C$ virus core protein. Virology 264: $134-141$

94. Ray RB, Steele R, Meyer K and Ray R (1998) Hepatitis C virus core protein represses p21WAF1/Cip1/Sid1 promoter activity. Gene 208: 331-336 
95. Otsuka M, Kato N, Lan K, Yoshida H, Kato J, Goto T, Shiratori Y and Omata M (2000) Hepatitis C virus core protein enhances p53 function through augmentation of DNA binding affinity and transcriptional ability. J. Biol. Chem. 275: $34122-34130$

96. Okuda M, Li K, Beard MR, Showalter LA, Scholle F and Weinman SA (2002) Mitochondrial injury, oxidative stress, and antioxidant gene expression are induced by hepatitis $C$ virus core protein. Gastroenterology 122: 369-375

97. Fujita T, Ishido S, Muramatsu S, Itoh M and Hotta H (1996) Suppression of actinomycin D-induced apoptosis by the NS3 protein of hepatitis C virus. Biochem. Biophys. Res. Commun. 229: 825-831

98. Gosh A (2000) Hepatitis C Virus NS5A protein protects against TNF-alpha mediated apoptotic cell death. Virus Res. 67: 173-178

99. Enomoto N, Sakuma I, Asahina Y, Kurosaki M, Murakami T, Yamamoto C, Ogura $Y$, Izumi N, Marumo F and Sato C (1996) Mutations in the nonstructural protein $5 \mathrm{~A}$ gene and response to interferon in patients with chronic hepatitis $\mathrm{C}$ virus $1 \mathrm{~b}$ infection. N. Engl. J. Med. 334: 77-81

100. Honda A, Hatano M, Kohara M, Arai Y, Hartatik T, Moriyama T, Imawari M, Koike K, Yokosuka O, Shimotohno K and Tokuhisa T (2000) HCV-core protein accelerates recovery from the insensitivity of liver cells to Fas-mediated apoptosis induced by an injection of anti-Fas antibody in mice. J. Hepatol. 33 : 440-447

101. Machida K, Tsukiyama-Kohara K, Seike E, Tone S, Shibasaki F, Shimizu M, Takahashi H, Hayashi Y, Funata N, Taya C, Yonekawa H and Kohara M (2001) Inhibition of cytochrome $\mathrm{c}$ release in Fas-mediated signaling pathway in transgenic mice induced to express hepatitis $\mathrm{C}$ viral proteins. J. Biol. Chem. 276: $12140-12146$

102. Chisari FV (1997) Cytotoxic T cells and viral hepatitis. J. Clin. Invest. 99: 1472 1477

103. Rehermann B, Chang KM, McHutchinson J, Kokka R, Houghton M, Rice CM and Chisari FV (1996) Differential cytotoxic T-lymphocyte responsiveness to the hepatitis B and C viruses in chronically infected patients. J. Virol. 70: 7092 7102

104. Hiroishi K, Kita H, Kojima M, Okamoto H, Moriyama T, Kaneko T, Ishikawa T, Ohnishi S, Aikawa T, Tanaka N, Yazaki Y, Mitamura K and Imawari M (1997) Cytotoxic $\mathrm{T}$ lymphocyte response and viral load in hepatitis $\mathrm{C}$ virus infection. Hepatology 25: 705-712

105. Piazzolla G, Tortorella C, Fiore G, Serrone M, Caccetta L, Jirillo E, Schiraldi O and Antonaci S (1998) Immunoresponsiveness in chronic hepatitis $C$ patients: correlation between tissue and serum findings. Immunopharmacol. Immunotoxicol. 20: 337-354

106. Yao ZQ, Nguyen DT, Hiotellis Al and Hahn YS (2001) Hepatitis C virus core protein inhibits human lymphocyte responses by a complement-dependent regulatory pathway. J. Immunol. 167: 5264-5272

107. Tseng CTK and Klimpel GR (2002) Binding of the hepatitis C virus envelope protein E2 to CD81 inhibits natural killer cell functions. J. Exp. Med. 195: 43-49

108. Emi K, Nakamura K, Yuh K, Sugyo S, Shijo H, Kuroki M and Tamura K (1999) Magnitude of activity in chronic hepatitis $\mathrm{C}$ is influenced by apoptosis of $\mathrm{T}$ cells responsible for hepatitis $C$ virus. J. Gastroenterol. Hepatol. 14: 1018-1024

109. Nakamoto $Y$, Kaneako S and Kobayashi K (2001) Monocyte-dependent cell death of T lymphocyte subsets in chronic hepatitis C. Immunol. Lett. 78: 167174

110. Toubi E, Kessel A, Goldstein L, Slobodin G, Sabo E, ShmuelZandZuckermanE (2001) Enhanced peripheral T-cell apoptosis in chronic hepatitis $C$ virus infection: association with liver disease severity. J. Hepatol. 35: 774-780

111. Taya N, Torimoto Y, Shindo M, Hirai K, Hasebe C and Kohgo Y (2000) Fasmediated apoptosis of peripheral blood mononuclear cells in patients with hepatitis C. Br. J. Haematol. 110: 89-97

112. Zheng L, Fisher G, Miller RE, Peschon J, Lynch DH and Lenardo MJ (1995) Induction of apoptosis in mature T cells by tumour necrosis factor. Nature 377: 348-351

113. Galle PR, Hofmann WJ, Walczak H, Schaller H, Otto G, Stremmel W, Krammer $\mathrm{PH}$ and Runkel L (1995) Involvement of the CD95 (APO-1/Fas) receptor and ligand in liver damage. J. Exp. Med. 182: 1223-1230
114. Moriya K, Fujie H, Shintani Y, YotsuyanagiH, Tsutsumi T, IshibashiK, Matsuura Y, Kimura S, Miyamura Tand Koike K (1998) The core protein of hepatitis C virus induces hepatocellular carcinoma in transgenic mice. Nat. Med. 4: 1065-1067

115. Lerat H, Honda M, Beard MR, Loesch K, Yang Y, Okuda M, Gosert R, Xiao SY, Weinman SA and Lemon SM (2002) Steatosis and liver cancer in transgenic mice expressing the structural and nonstructural proteins of hepatitis $C$ virus. Gastroenterology 122: 342-365

116. Higaki K, Yano H and Kojiro M (1996) Fas antigen expression and its relationship with apoptosis in human hepatocellular carcinoma and noncancerous tissues. Am. J. Pathol. 149: 429-432

117. Strand S, Hofmann WJ, Hug H, Muller M, Otto G, Strand D, Mariani SM, StremmeIW, Krammer PH and Galle PR (1996) Lymphocyte apoptosis induced by CD95 (APO-1/Fas) ligand-expressing tumor cells-a mechanism of immune evasion? Nat. Med. 2: 1361-1366

118. Kato N, Yoshida H, Kioko Ono-Nita S, Kato J, Goto T, Otsuka M, Lan K, Matsushima K, Shiratori Y and Omata M (2000) Activation of intracellular signaling by hepatitis $\mathrm{B}$ and $\mathrm{C}$ viruses: $\mathrm{C}$-viral core is the most potent signal inducer. Hepatology 32: 405-412

119. Tai DI, Tsai SL, Chen YM, Chuang YL, Peng CY, Sheen IS, Yeh CT, Chang KS, Huang SN, Kuo GC and Liaw YF (2000) Activation of nuclear factor kappaB in hepatitis $C$ virus infection: implications for pathogenesis and hepatocarcinogenesis. Hepatology 31: 656-664

120. Liu H, Lo CR and Czaja MJ (2002) NF-kappaB inhibition sensitizes hepatocytes to TNF-induced apoptosis through a sustained activation of JNK and c-Jun. Hepatology 35: 772-778

121. Heim MH, Moradpour D and Blum HE (1999) Expression of hepatitis $C$ virus proteins inhibits signal transduction through the Jak-STAT pathway. J. Virol.73: 8469-8475

122. Shrivastava A, Manna SK, Ray R and Aggarwal BB (1998) Ectopic expression of hepatitis $C$ virus core protein differentially regulates nuclear transcription factors. J. Virol. 72: 9722-9728

123. Boya P, Larrea E, Sola I, Majano PL, Jimenez C, Civeira MP and Prieto J (2001) Nuclear factor-kappa $B$ in the liver of patients with chronic hepatitis $C$ : decreased RelA expression is associated with enhanced fibrosis progression. Hepatology 34: 1041-1048

124. Beg AA, Sha WC, Bronson RT, Ghosh S and Baltimore D (1995) Embryonic lethality and liver degeneration in mice lacking the RelA component of NFkappa B. Nature 376: 167-170

125. Yamada Y, Kirillova I, Peschon JJ and Fausto N (1997) Initiation of liver growth by tumor necrosis factor: deficient liver regeneration in mice lacking type I tumor necrosis factor receptor. Proc. Natl. Acad. Sci. USA 94: 1441-1446

126. FrommelTO, Yong S and Zarling EJ (1999) Immunohistochemical evaluation of $\mathrm{Bcl}-2$ gene family expression in liver of hepatitis $\mathrm{C}$ and cirrhotic patients: a novel mechanism to explain the high incidence of hepatocarcinoma in cirrhotics. Am. J. Gastroenterol. 94: 178-182

127. Yanagi M, Purcell RH, Emerson SU and Bukh J (1997) Transcripts from a single full-length CDNA clone of hepatitis $C$ virus are infectious when directly transfected into the liver of a chimpanzee. Proc. Natl. Acad. Sci. USA 94: 87388743

128. Kolykhalov AA, Agapov EV, Blight KJ, Mihalik K, Feinstone SM and Rice CM (1997) Transmission of hepatitis $C$ by intrahepatic inoculation with transcribed RNA. Science 277: $570-574$

129. Lohmann V, Korner F, Koch J, Herian U, Theilmann L and Bartenschlager R (1999) Replication of subgenomic hepatitis $C$ virus RNAs in a hepatoma cell line. Science 285: 110-113

130. Mercer DF, Schiller DE, Elliott JF, Douglas DN, Hao C, Addison WR, Fischer KP, Churchill TA, Lakey JR, Tyrrell DL and Kneteman NM (2001) Hepatitis C virus replication in mice with chimeric human livers. Nat. Med. 7: 925-933 